\section{Transaksi Bisnis Online dalam Perspektif Islam}

\author{
Siti D wi Pujiyanti*, Anis Wahdi \\ Program Studi Perbankan Syariah, STAI Sayid Sabiq \\ Indramayu Jawa Barat
}

\begin{abstract}
A bstract
Purpose-The purpose of this research is to find out and explore the online business transactions implemented by the Tokopedia application and online business transactions in the Islamic perspective on the Tokopedia application case study. Methods- This study is a qualitative research method, namely by using the Library Search (Literature R eview) field by taking references from several books and sources from websites or the internet. Findings- From the results of this study, it can be concluded that the transaction of buying and selling online on the Tokopedia application is perfectly legal in Islamic law. A s long as there is no element of deception or fraud or the desired item is incomplete or defective (not as expected) that occurs during the transaction process. Even if this happens, the responsible party is obliged to return all buyer's money and the sale and purchase is considered invalid because it does not meet the trading agreement.
\end{abstract}

\begin{abstract}
A bstrak
Tujuan-penelitian ini bertujuan untuk mengetahui dan mengeksplorasi transaksi bisnis online yang dilaksanakan oleh aplikasi Tokopedia dan transaksi bisnis online dalam perspektif Islam pada studi kasus aplikasi Tokopedia. Metode- Penelitian ini adalah metode penelitian kualitatif, yaitu dengan menggunakan bidang Pencarian Perpustakaan (Literature Review) dengan mengambil referensi dari beberapa buku dan sumber dari situs web atau internet. Temuan- Dari hasil penelitian ini, dapat disimpulkan bahwa transaksi jual beli online pada aplikasi Tokopedia sangat legal dalam hukum Islam. Selama tidak ada unsur penipuan atau penipuan atau item yang diinginkan tidak lengkap atau rusak (tidak seperti yang diharapkan) yang terjadi selama proses transaksi. Bahkan jika ini terjadi, pihak yang bertanggung jawab berkewajiban mengembalikan semua uang pembeli dan jual beli dianggap tidak sah karena tidak memenuhi perjanjian perdagangan.
\end{abstract}

Pedoman Sitasi: Pujiyanti, S., \& Wahdi, A. (2020). Transaksi Bisnis Online dalam Perspektif Islam. SERAMBI: Jurnal Ekonomi $M$ anajemen Dan Bisnis Islam, 2(2), 91 - 102

D O I: https:/ / doi.org/ 10.36407/ serambi.v2i2.173

\section{SERAM BI}

Received 06 Mei2020

Revised 16Jun 2020

Accepted 20 Jun 2020

Online first 30 Jun 2020

\section{Paper type}

Literature review

Email Korespondensi*: pujidwi44@yahoo.com

Keywords: business online transaction, islamic perspective

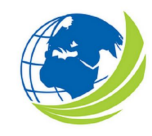

SERAMBI: Jurnal Ekonomi dan Bisnis Islam, Vol 2, No.2, 2020, pp. 91-102 eISSN 2685-9904 


\section{Pendahuluan}

Bisnis online adalah bisnis dengan menggunakan media internet sebagai media pemasaran suatu produk atau jasa.Produk yang dipasarkan berupa produk barang, produk digital, dan jasa.Contoh produk barang adalah pakaian, makanan, elektronik, dan lain-lain.Sedangkan untuk produk digital adalah e-book, video, audio, dan software.Untuk jenis jasa dapat berupa desain grafis, jasa penerjemah, dan lain sebagainya.Berbisnis dengan menawarkan jasa dan barang dagangan di ecommerce jenis marketplace kini sedang banyak diminati oleh masyarakat.Hal ini disebabkan oleh kemudahan akses, efesiensi waktu dan pengurangan biaya yang dapat dikontrol dengan memanfaatkan media internet. Internet tersebut telahmenciptakan suatu ekonomi baru, yang sudah mengubah persepsi kita tentang cara melakukan bisnis tradisional. Banyak perusahaan kecil dan perusahaan menengah berhasil membangun bisnis online yang terbukti sangat menguntungkan. Studi menunjukan perusahaan kedi maupun perusahaan menengah akan menjadi suatu kekuatan pertumbuhan utama e-commerce dalam tahun-tahun mendatang (Timothy, 2010).

Tak bisa dipungkiri bahwa keberadaan generasi milenial saat ini kian semarak didunia kerja.Mereka berbeda dengan generasi-generasi sebelumnya. Mereka selalu memegang prinsip muda, semangat, penuh gaya. Mereka juga mempunyai wawasan luas, berpengetahuan, serta mampu berpikir cerdas.Mereka belajar dari manapun, terutama dari sumber-sumber yang ada diinternet.Generasi milenial tidak suka melakukan hal-hal yang menyulitkan dan melelahkan sebagaimana dilakukan generasi sebelumnya.Mereka lebih suka duduk santai didepan komputer dan bekerja ringan dengan menjelajah dunia maya (Afifi, 2019).Dalam perkembangan selanjutnya, ternyata internet juga telah melahirkan jutawan-jutawan baru.Dalam arti, mulai banyak orang yang menggunakan media internet sebagai sarana berbisnis (bisnis Online).Dari pengalaman sebagian besar orang, ternyata banyak sekali peluang bisnis yang dapat dilakukan menggunakan internet.Pada dasarnya bisnis dunia maya tidak berbeda dengan bisnis didunia nyata.Bisnis dunia maya juga memerlukan ketekunan dan keseriusan (Purkon, 2014).

Salah satu contoh transaksi online adalah penjualan produk secara online melalui internet seperti Tokopedia.com. dalam bisnis ini dukungan dan pelayanan konsumen dapat kita lakukan dengan W ebsite, Email dan W hatsapp sebagai alat bantu, berkomunikasi, mengirimkan kontak dan sebagainya.Tokopedia memungkinkan setiap orang yang memiliki produk maupun jasa membuka dan mengurus toko secara gratis, aman, dan nyaman dengan berbagai fitur yang diberikan secara lengkap dan praktis. Sejak peluncuran situs Tokopedia.com secara resmi pada tanggal 17 Agustus 2009, Tokopedia.com menjadi salah satu situs jual beli yang banyak diakses oleh masyarakat khususnya di Indonesia.Hal ini tentunya menjadi peluang besar bagi penjual untuk mendapatkan hasil penjualan yang lebih dan menjadi kemudahan bagi pembeli dalam mencari dan mendapatkan produk yang di inginkan.

Bisnis online dan offline dalam perspektif Islam adalah proses transaksi akadnya dan media utama dalam proses tersebut. A kad merupakan unsur yang sangat penting dalam suatu bisnis atau jual beli.Secara umum, bisnis dalam islam menjelaskan adanya transaksi yang bersifat fisik, dengan menghadirkan benda tersebut ketika kita bertansaksi atau tanpa menghadirkan benda yang dipesan, tetapi dengan ketentuan harus dinyatakan sifat benda secara jelas, baik diserahkan secara langsung maupun diserahkan kemudian sampai batas waktu yang dijanjikan.Transaksi as-salam merupakan bentuk transaksi dengan system pembayaran secara tunai/ disegerakan tetapi penyerahan barang ditangguhkan.Sedang transaksi al-istisna merupakan bentuk transaksi dengan system pembayaran secara disegerakan atau secara ditangguhkan sesuai kesepakatan dan penyerahan barang yang ditangguhkan. Karna itu, jual 
beli online sebenarnya hampir sama bentuknya dengan jual beli transaksi as-salam dan al-istishna, yaitu bentuk transaksi dengan system pembayaran secara tunai/ diselenggarakan tetapi penyerahan barang ditangguhkan. Atau sebaliknya pembayaran ditangguhkan tetapi penyerahan barang disegerakan atau dapat pula dilakukan sesuai kesepakatan kedua belah pihak

Sayangnya banyak sekali kaum milenial yang tidak mengerti bagaimana transaksi bermuamalah online dengan baik dan benar. Di Indonesia, berbagai ketentuan yang berkaitan dengan bisnis syariah telah dirumuskan dalam fatwa-fatwa yang dikeluarkan oleh Dewan Syariah Nasional Majelis Ulama Indonesia (DSN-MUI). Fatwa-fatwa tersebut berisi aturan dan ketentuan hukum yang berkaitan dengan berbagai bentuk bisnis konteporer ditinjau dari perspektif islam.Tujuan penelitian untuk mengetahui dan mendalami tentang : transaksi bisnis online yang diterapkan oleh aplikasi Tokopedia. Kegunaan penelitian ini diharapkan dapat digunakan dan dimanfaatkan sebagai salah satu masukan atau sumbangan ilmu pengetahuan dibidang keilmuan maupun pengembangan ilmiah dari penulis maupun pembaca tentang transaksi bisnis online dalam perspektif islam pada studi kasus aplikasi Tokopedia. Selain itu, dari sisi praktis, hasil studi ini dapat membantu mayarakat saat melakukan pembelian maupun penjualan menggunakan website situs ecommerce.

\section{Kerangka konsep}

Tokopedia.com merupakan sebuah toko online yang dimiliki oleh Indonesia.W ebsite ini menjual berbagai macam barang elektronik, peralatan kantor, peralatan rumah tangga, peralatan olahraga, kosmetik, perlengkapan bayi, dan lainnya. Tokopedia dilengkapi dengan mesin pencari yang akan memudahkan pencarian barang yang diinginkan. Tokopedia bekerjasama dengan agen pengiriman besar di Indonesia yang mempermudah untuk memeriksa status pengiriman barang. Keuntungan bagi pembeli dengan pembayaran yang unik adalah proses verifikasi pembayaran yang instan, yang memungkinkan penjual lebih cepat menerima order dan barang yang dijual bisa lebih cepat sampai ke pembeli. Untuk penjual, keuntungan yang ditawarkan adalah perluasan pasar pada para pengguna untuk yang ingin membeli di Tokopedia.Pilihan pembayaran pada transaksi online lebih cepat dan mudah.Dapat dikatakan Tokopedia merupakan penyempurnaan dari situs-situs jual beli online sebelumnya. Tokopedia memiliki beberapa fitur unggulan yang tidak ditemukan pada situs-situs lainnya. Berikut adalah alur transaksi pada A plikasi Tokopedia (Gregorius, 2012).

Dari perspektif Islam, e-commerce menunjukkan konotasi yang sama dengan cara perdagangan konvensional.Oleh karena itu, harus sesuai dengan semua persyaratan dan prinsip hukum kontrak Islam seperti bebas dari unsur riba (riba), perjudian (maysir), ketidakpastian (gharar) dan paksaan (ikrah). Persyaratan Syariah ini bertujuan melindungi kepentingan dan menghilangkan bahaya pihak-pihak yang terlibat dalam suatu transaksi, dengan demikian mempromosikan keadilan, yang merupakan salah satu tujuan utama Syariah (maqasidalSyariah). Karena e-commerce melibatkan perdagangan antara pembeli dan penjual, ia perlu memenuhi persyaratan dan ketentuan penting dari hukum kontrak Islam, yaitu (i) penawaran dan penerimaan (formulir), (ii) pembeli dan penjual (pihak yang mengadakan kontrak) dan (iii) objek dan harga (subjek), maka dianggap sah. (Muhammad et al., 2013).

Mutiarasari (2019) mengimplementasikan perkembangan teknologi yang semakin maju mengakibatkan pergeseran kebiasaan diberbagai aspek kehidupan.Dengan kemajuan duania internet ini, melalui beraneka ragam kemajuan peralatan teknologi informasi dan komunikasi yang ada, para individu maupun kelompok-kelompok masyarakat saling berinteraksi dalam 
berbagai aktivitas kehidupan, tidak terkecuali dalam kegiatan jual beli.Salah satu kemudahan yang ditawarkan dengan adanya perkembangan teknologi ialah bisnis online yang sangat terkenal yaitu e-commerce, merupakan sejenis marketplace tempat dimana terjadinya transaksi bisnis online.akad merupakan unsur yang paling penting dalam suatu bisnis. Akad atau ijab qabul dilaksanakan dengan ucapan lisan, tulisan atau isyarat bagi mereka yang tidak mampu berbicara atau menulis. Perlunya pencatatan dalam melakukan bisnis online merupakan hal yang sangat penting, karena barang yang dibeli baru akan diproses dan dikirim setelah pembeli melakukan pembayaran terlebih dahulu. Didalam transaksi jual beli online, prinsip kejujuran menjadi sangatlah rentan karena penjual dan pembeli tidak bertemu secara langsung , melainkan melalui bisnis online atau media social.

Menurut M.H.Tirtaadmijaja, hukum adalah semua aturan (norma) yang harus ditaati dalam pergaulan hidup dan bila dilanggar akan diberikan sanksi (Mardani, 2014). Purkon (2014) menjelaskan bahwa dalam islam, hukum asal segala transaksi adalah dibolehkan, selama tidak ada dalil AI-Quran atau sunah yang mengharamkannya. Dengan demikian, apabila ada bentuk baru transaksi bisnis, perlu dikaji apakah ada dalil AI-Quran atau sunah yang mengharamkan atau tidak.Kalau ada yang mengharamkan, hukumnya menjadi haram (terlarang).Sebaliknya, jika tidak ada dalil AI-Quran yang mengharamkan, hukumnya mubah (diperbolehkan).Berikut adalah Hadist yang menjel askan tentang suka sama suka dalam jual beli :

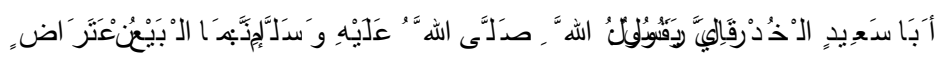

Dari Abu Sa'id Al Khudri berkata: Rosululloh bersabda "Sesungguhnya jual beli itu atas dasar suka sama suka."

Hadits ini yang diriwayatkan oleh Ibnu Majah 2/ 737 no: 2185 dari jalan Abu Said Al Khudri. Berkata Al Bushiri dalam Az Zawaid: Sanadnya shohih dan para perowinya terpercaya. Juga dishohihkan oleh Syaikh AI Albani dalam Shohih Ibnu M ajah: 1792 dan Irwa: 1283.Setiap muslim yang berbisnis harus memperhatikan aturan hukum islam ketika melakukan aktivitas bisnis, termasuk jika berbisnis online. Ini dikarenakan tujuan bisnis dalam islam selain mencari keuntungan materi, juga untuk mendapat keberkahan dari harta (materi) yang diperoleh. Keberkahan akan didapatkan apabila materi tersebut didapatkan dan dikelola sesuai dengan ketentuan syariah. Karena bisnis didunia maya sama seperti bisnis didunia nyata, aturan bisnisnya secara umum sama.Suatu transaksi atau akad dinyatakan sah apabila terpenui syarat dan rukunnya. Dalam hukum islam ada beberapa rukun dan syarat berkaitan dengan suatu akad (transaksi), yaitu :

Pertama, adanya dua pihak atau lebih yang melakukan akad (transaksi).Secara umum, orang yang melakukan akad (transaksi) disyaratkan memiliki kecakapan hukum dan kemampuan untuk melakukan akad (mampu menjadi pengganti orang lain jika ia menjadi wakil). Dalam bisnis online, masing-masing pihak yang terlibat dalam transaksi harus memenuhi ketentuan-ketentuan untuk validitas transaksi itu sendiri.Kedua pihak harus memenuhi ketentuan memiliki kecakapan hukum dan mempunyai wewenang untuk melakukan transaksi. Kedua, ada sighat akad. Shigat akad adalah sesuatu yang menunjukan apa yang ada dihati pihak yang melakukan akad akan terjadinya sebuah akad. Sighat biasanya disebut ijab dan qabul.ljab adalah penetapan perbuatan tertentu yang menunjukkan keridaan yang diucapkan pihak pertama, baik yang menyerahkan maupun yang menerima, sedangkan qabul adalah orang yang berkata setelah orang yang mengucapkan ijab, perkataan tersebut menunjukan keridhaan 
atas ucapan orang yang pertama. Pernyataan ijab dan qabul dapat dilakukan secara lisan, tulisan, surat menyurat, isyarat atau bentuk lain yang memberi pengertian dengan jelas tentang adanya ijab dan qabul. Dapat juga berupa perbuatan yang telah menjadi kebiasaan dalam ijab dan qabul.Pada dasarnya, ijab dan qabul dalam bisnis online sama dengan ijab dan qabul dalam bisnis di dunia nyata. Pernyataan ijab dan qabul (kesepakatan) dapat dilakukan dengan berbagai cara dan melalui berbagai media. Namun, yang terpenting adalah substansi ijab dan qabul (kesepakatan) tersebut dapat dipahami maksudnya oleh kedua pihak yang melakukan transaksi, sehingga dapat diartikan sebagai kerelaan kedua pihak untuk melakukan transaksi.Dalam bisnis online, kedua pihak secara fisik tidak bertemu disuatu tempat.Namun, mereka bertemu dalam satu majelis, yaitu majelis maya.

Ketiga, ada objek akad.Barang atau jasa yang menjadi objek akad harus sesuai dengan ketentuan syara, yaitu objek harus halal, suci (tidak najis), dapat diserahterimakan, dan diketahui oleh kedua belah pihak.Objek dalam bisnis online umumnya berupa jasa, komoditi digital, atau non digital.Hal ini tidak jauh berbeda dengan bisnis dunia nyata. Karena itu, objek dalam bisnis online harus memenuhi kriteria yang disyaratkan, yaitu berupa jasa atau komoditi yang halal, mempunyai nilai dan manfaat, memiliki kejelasan baik bentuk, fungsi maupun keadaannya, serta dapat diserahterimakan pada waktu, tempat (media) yang telah disepakati. Dengan demikian, menurut hukum islam, transaksi bisnis online diperbolehkan apabila sesuai dengan prinsip atau ketentuan akad yang ada dalam hukum islam (Purkon, 2014).

Yulianti (2019) memberikan penjelasan bahwa transaksi jual beli ditengah masyarakat digital sekarang ini erat kaitannya dengan toko online skala rumahan hingga pasar online yang menampung ribuan pelapak dengan berbagai macam produk jualannya.Pelanggan disuguhkan kemudahan, kecepatan, kenyamanan dan keamanan dalam bertansaksi, sehingga dapat menghemat waktu dan biaya.Praktek jual beli didunia maya yang ramai dilakukan saat ini ternyata memunculkan kriminalitas di dunia maya yang jelas sekali merugikan penjual maupun pembeli.Bahkan kini pihak kepolisian membentuk Cyber Crime yang khusus menangani kriminalitas transaksi didunia maya.Pandangan Islam terhadap etika bersifat mutlak bukan relative, memiliki pondasi yang kuat yang mendasarkan pada prinsip-prinsip kejujuran dan keadilan. Manusia diberikan batasan dalam memperoleh harta dan bersikap tidak tamak serta menerapkan nilai-nilai yang sesuai syariat karena semua perilaku akan dipertanggung jawabkan dihadapan Allah.

Agung (2011), dalam bukunya Rahasia Sukses Buka Lapak Jualan Di Tokopedia tentang transaksi bisnis oterjadi hanya dilandas dengan rasa saling percaya antara penjual dengan pembeli, sehingga tidak jarang pembeli yang belum berpengalaman tertipu oleh penjual-penjual yang berniat jahat. Pembeli yang sudah mentransfer uangnya kerekening penjual tidak akan pernah menerima uang yang sudah dibayarnya karena penjual telah menipunya. Namun demikian kasus-kasus penipuan terebut tidak membuat kapok para penjual dan pembeli lainnya untuk tetap bertransaksi secara online.Hal ini karena para penjual merasa diuntungkan dengan banyaknya pengunjung situs forum yang secara otomatis menjadi pangsa pasar potensial. Selain itu, tidak semua orang memiliki kemampuan intelegensi dan dana yang mencukupi untuk membangun sebuah website khusus E-commerce. Untuk itulah, Wiliam Tanuwijaya bersama Leontinus Al pha Edision membangun Tokopedia, sebuah solusi transaksi online melalui website E-commerce yang besar dan terpercaya.Tokopedia terus berbenah dan mampu bertahan hingga sekarang.Tokopedia juga mampu bertahan dari beberapa kasus penipuan yang dilakukan oknum penjual di Tokopedia.Tokopedia dengan tegas menutup toko penjual dan nomor rekening penjual tidak dapat didaftarkan lagi sebagai penjual di Tokopedia. 


\section{Metodologi}

Desain penelitian

Penelitian ini dilakukan dengan mengambil lokasi penelitian di kampus STAI Sayid Sabiq Indramayu khususnya di Program Studi Perbankan Syariah dan Pendidikan Agama Islam, dengan alasan maraknya jual beli online dikalangan Mahasiswa Perbankan Syariah dan Pendidikan Agama Islam STAI Sayid Sabiq Indramayu maka dari itu penulis antusiasi untuk dijadikannya sebagai bahan penelitian.Penelitian ini menggunakan rancangan penelitian deskriptif kualitatif. Data penelitian yang berupa paparan data mengenai bagaimana bertansaksi melalui online yang aman dan syar'i dikalangan Mahasiswa STAI Sayid Sabiq Indramayu Program Studi Perbankan Syariah dan Pendidikan Agama Islam, pengumpulan data dilakukan dengan menggunakan teknik wawancara dan observasi.Instrument yang di gunakan untuk mengumpulkan data berupa instrument manusia yaitu peneliti sendiri dengan alat-alat yang digunakan.

Pendekatan penelitian yang akan digunakan pada penelitian ini adalah studi kasus, adalah suatu model penelitian kualitatif yang terperinci tentang individu atau suatu unit social tertentu dalam kurun waktu tertentu. Secara mendalam studi kasus merupakan suatu model yang bersifat komperehansif, intens, terperinci dan mendalam serata lebih diarakan sebagai upaya untuk menelaah masalah-masalah atau fenomena-fenomena yang bersifat kontemporer (Syaodih, 2006). Tujuan studi kasus adalah untuk memberikan gambaran secara mendetail tentang latar belakang, sifat-sifat serta karakter-karakter yang khas dari kasus, ataupun status dari individu, yang kemudian,dari sifat-sifat khas akan dijadikan suatu hal yang bersifat umum (Hendriansyah, 2010).

\section{Data dan metode pengumpulan data}

Data primer adalah data yang diperoleh langsung dilokasi penelitian yaitu di STAI Sayid Sabiq Indramayu Program Studi Perbankan Syariah dan Pendidikan Agama Islam. Sumber data primer ini adalah hasil dari wawancara terhadap pihak-pihak yang melakukan transaksi online di kampus yang akan di bahas di lokasi penelitian. Bahan penelitian kepustakaan ini menghasilkan data sekunder yang diperoleh dari buku, jurnal, laporan dan dokumen lainnya yang berhubungan dengan penelitian serta dua bahan hokum, baik berupa bahan hokum primer maupun bahan hukum sekunder. Seperti AI-Quran dan AI-Hadits, serta literature lain yang ada hubungannya degan topik ini.

\section{Teknik analisis data}

Teknik analisis data bertujuan untuk menguraikan dan memecahkan masalah berdasarkan data yang diperoleh.Analisis yang digunakan yaitu analisis data kualitatif. Analisis data kualitatif adalah upaya yang dilakukan dengan jalan bekerja dengan data, mengorganisasikan data, memilah-milah menjadi satuan yang dapat dikelolah, mencari dan menemukan pola, menemukan apa yang penting apa yang dipelajari, dan memutuskan apa yang dapat di ceritakan kembali dengan data-data yang berasal dari literature bacaan

\section{Hasil dan pembahasan}

Prinsip etika bisnis di Tokopedia

Etika sebagai ilmu pengetahuan merupakan cabang filsafat tentang tingkah laku manusia dengan focus utama penentuan baik dan buruk. Sebagai ilmu pengetahuan tentang asas-asas akhlak atau kumpulan asas atau nilai yang berkenaan dengan akhlak, etika mempersoalkan 
pengkajian moralitas dan nilai tindakan moral, sehingga dapat diaplikasikan pula pada pada system atau kode yang dianut. Demikian dalam islam tidak hanya keuntungan duniawi semata tapi keuntungan materi yang halal yang penuh berkah yang akan membawa kebahagiaan di dunia dan di akhirat. Prinsip etika bisnis islam yang merupakan aksioma-aksioma etik yang meliputi keesaan, kehendak bebas, tanggung jawab dan kebajikan.

\section{Keesaaan}

Konsep tauhid yang memadukan keseluruhan aspek-aspek kehidupan muslim baik dalam bidang ekonomi, politik, sosial menjadi keseluruhan yang homogen, serta mementingkan konsep konsistensi dan keteraturan yang menyeluruh. Dari konsep ini maka Islam menawarkan keterpaduan agama, ekonomi, dan sosial demi membentuk kesatuan.Atas dasar pandangan ini pula maka etika dan bisnis menjadi terpadu, vertikal maupun horizontal. Penerapan konsep ini pada anggota Tokopedia yang berhubungan langsung dengan kewajibanya sebagai muslim adalah kejujuran dalam setiap transaksi. Bersikap seperti Allah sedang mengawasi dalam bisnis dapat diimplikasikan oleh responden adalah menulis deskripsi produk pada kolom keterangan sesuai dengan kondisi produk.

Seperti yang diamati peneliti pada salah satu toko online responden Leni Program Studi Pendidikan Agama Islam yang menuliskan deskripsi poduk sesuai dengan kondisinya dan menjelaskan kekurangan/ kecatatan produk melalui chat dengan pembeli. Dalam wawancara Leni menyebutkan bahwa "Deskripsi produk adalah salah satu al at jualan di Tokopedia, semakin lengkap deskripsi yang ditulisdan menuliskan kondisi sebenarnya dari produk yang kita jual maka semakin orang tertarik untuk membelinya. Ini sama seperti alat komunikasi satu arah, dimana sebagai penulis kita mendiskripsikan barang dengan jelas, menarik dan tegas. Penjual tidak menyembunyikan kondisi barang jualanya mempermudah pembeli untuk mengambil keputusan membeli atau tidak".Dengan demikian responden menunjukan respon positif terhadap aksioma keesaan dimana responden melaksanakan kewajibanya tanpa paksaan, konsisten dan merasa Allah tahu segala yang diperbuat.Dalam penerapanya, responden bersikap jujur dalam memberikan keterangan kondisi produk dan melakukanya sebagai bentuk ibadah.

Kehendak bebas

Pada tingkat tertentu, manusia diberikan kehendak bebas untuk mengendalikan kehidupannya sendiri manakala Allah SWT menurunkannnya ke bumi. Konsep ini dalam aktivitas ekonomi mengarahkan kepada kebaikan setiap kepentingan untuk seluruh komunitas Islam dengan adanya larangan bentuk monopoli, kecurangan, ingkar janji dan praktik penipuan adalah jaminan terhadap terciptanya suatu mekanisme pasar yang sehat dan persamaan peluang untuk berusaha tanpa adanya keistimewaan-keistimewaan pada pihak-pihak tertentu (Indri dan Rutik, 2008).

Penerapan kehendak bebas pada etika bisnis Islam di Tokopedia Commuinity yaitu melakukan usaha untuk mengembangkan bisnisnya. Di Tokopedia sendiri tersedia fasilitas iklan berbayar dan Gold M erchant, yaitu fitur berbayar untuk para penjual di Tokopedia.Gold M erchant dilengkapi fiturfitur pendukung yang dapat membantu seller meningkatkan penjualannya di Tokopedia. Salah satu fitur yang dapat lihat langsung adalah fitur "Gold Badge", dimana icon "Gold Badge" ini dapat dilihat saat melakukan pencarian produk."Emblem Gold Badge" ini hanya bisa didapatkan apabilaseller sudah mencapai shop score 75 dari 100.

Fitur ini mendapat respon positif dari pedagang di Tokopedia seperti yang diuangkapkan Trio Sardi Program Studi Perbankan Syariah sebagai berikut : “Manfaat gold merchant terasa 
sekali, kita bisa berada di urutan pertama pencarian produk dan berada di halaman depan pencarian produk merupakan salah satu peluang mendapatkan pembeli. Beberapa pembeli memang melihat harga yang paling rendah dengan fitur filter harga tapi tidak sedikit yang mementingkan kualitas seperti review produk, review toko, jumlah bintang dan gold merchant".

Konsep kebebasan dalam Islam lebih mengarah pada kerja sama, bukan persaingan apalagi sampai mematikan usaha satu sama lain. Kalaupun ada persaingan dalam usaha, maka itu berarti persaingan dalam berbuat kebaikan atau fastabiq al-khairat (berlombalomba dalam kebajikan).

\section{Tanggungjawab}

Kebebasan tanpa batas adalah suatu hal yang mustahil dilakukan oleh manusia karena tidak menuntut adanya pertanggungjawaban dan akuntabilitas.untuk memenuhi tuntunan keadilan dan kesatuan, manusia perlu mempertaggungjawabkan tindakanya secara logis prinsip ini berhubungan erat dengan kehendak bebas. Ia menetapkan batasan mengenai apa yang bebas dilakukan oleh manusia dengan bertanggungjawab atas semua yang dilakukannya.Menurut Sayyid Qutub Islam mempunyai prinsip pertanggung jawaban yang seimbang dalam segala bentuk dan ruang lingkupnya (Beekun, 2001).

Pada transaksi Tokopedia 3 dari 14 responden pernah mendapatkan bintang 1 yang artinya, pelanggan tidak puas dengan kualitas produk, layanan toko atau harga yang tidak sesuai. Hal semacam ini bagi toko online di Tokopedia merupakan penilaian negatif yang berdampak pada performa toko dan penilaian produk. Penjual yang menganggap hal ini adalah kesialan maka akan membiatkanya namun bagi toko yang mempertahankan performa toko akan mencari tahu kenapa pembeli memberi bintang 1 dan menanggapinya.

Seperti yang diungkapkan Afifah Program Studi Pendidikan Agama Islam sebagai berikut : “Bintang 1 untuk produk $X$ bagi saya tidak bisa saya terima karena produk dalam keadaan baik dan pengemasan baik, pembeli memberikan bintang 1 karena ada kerusakan pada kemasan saat ia terima maka saya pastikan kembali bahwa produk dalam keadaan baik meski kemasan rusak. Pembeli menjawab iya produk dalam keadaan baik hanya kemasan yang rusak, jadi saya perkirakan kemasan rusak karena human eror pada pengantaran.Tapi beruntungnya produk dalam keadaan baik jadi saya tidak memperpanjangnya lagi".

Tidak semua pembeli tahu bahwa Tokopedia memiliki fitur mediasi untuk memecahkan kesalahpahaman atau mungkin kesalahan yang dilakukan penjual pada pusat resolusi. Sehingga pembeli langsung memberikan penilaian pada review produk. Tanggung Jawab (Responsibility) terkait erat dengan tanggung jawab manusia atas segala aktifitas yang dilakukan kepada Tuhan dan juga tanggung jawab kepada manusia sebagai masyarakat. Karena manusia hidup tidak sendiri dia tidak lepas dari hukum yang dibuat oleh manusia itu sendiri sebagai komunitas sosial.Tanggung jawab kepada Tuhan tentunya diakhirat, tapi tanggung jawab kepada manusia didapat didunia berupa hukum-hukum formal maupun hukum non formal seperti sangsi moral dan lain sebagainya.

Kebajikan

Ihsan (kebajikan) artinya melaksanakan perbuatan baik yang memberikan manfaat kepada orang lain, tanpa adanya kewajiban tertentu yang mengharuskan perbuatan tersebut atau dengan kata lain beribadah dan berbuat baik seakan-akan melihat Allah.Dalam hal ini Tokopedia Community memiliki kegiatan sharing ilmu untuk meningkatkan pendapatan toko.Padahal jika dipahami lagi mereka adalah rival di Tokopedia meskipun beberapa toko memiliki produk jualan yang 
berbeda. Berbagi tips untuk toko pesaing agar mendatangkan pembeli tentu menjadi pengalaman luar biasa bagi Tokopedia Community karena mengesampingkan persaingan.

Seperti yang diungkapkan Rianti Program Studi Perbankan Syariah sebagai berikut : "Sebagai manusia normal tentu saya menginginkan toko saya ramai pembeli tanpa harus memperdulikan toko pesaing, akan tetapi berada di komunitas ini membuat saya semangat berbagi tips bisnis online karena mereka seperti keluarga bagi saya. Saya ingin tumbuh dan berkembang bersama dengan komunitas ini karena bagi saya semakin banyak berbagi semakin lebar pintu rejeki, banyak teman, banyak pengalaman dan yang paling penting sama-sama sukses itu menyenangkan".

Meskipun prakteknya masih ada anggota Tokopedia Communityyang belum memahami etika bisnis Islam, di karenakan mereka telah terbiasa dengan etika bisnis kapitalis yaitu bisnis yang hanya mementingkan keuntungan semata, serta minimnya pengetahuan yang mereka miliki terkait tentang etika bisnis Islam itu sendiri.

Hasil penelitian secara umum menunjukkan bahwa Tokopedia telah menerapkan etika bisnis Islam melalui keempat aksiomanya. Penerapan etika tauhid pada bisnis antara lain dapat dilihat dari kualitas produk, kinerja SDM, dan proses transaksi di Tokopedia. Penerapan etika keseimbangan pada sistem pengelolaan bisnis dapat dinilai dari kualitas produk dan pendistribusian yang dilakukan. Kualitas produks dan distribusi yang baik bertujuan untuk memberikan produk terbaik bagi konsumen serta melayani kebutuhan konsumen. Penerapan etika kehendak bebas dapat dilihat dari berbagi ilmu dan tips meramaikan toko meskipun beberapa anggota Tokopedia memiliki produk jualan yang sama. Penerapan etika tanggung jawab dilakukan penjual dengan cara memberikan respon pada komplain yang diajukan dengan menawarkan pilihan yang tidak memberatkan satu sama lain. Penerapan etika kebajikan (ihsan) dapat ditelusuri dari keempat etika yang telah diterapkan penjual di atas yang menunjukkan bahwa penjual telah benar-benar memberikan manfaat bagi berbagai aspek ekonomi, memberikan pelayanan terbaik, respon cepat, tidak mengecewakan, serta tidak menimbulkan mudharat bagi semua pihak.

Transaksi bisnis lewat online jika sesuai dengan aturan-aturan yang telah disebut di atas akan membawa kemajuan bagi masyarakat dan negara. Namun demikian, bukan berarti tidak ada rambu-rambu yang mengaturnya. Transaksi online diperbolehkan menurut Islam selama tidak mengandung unsur-unsur yang dapat merusaknya seperti kezhaliman, penipuan, kecurangan dan yang sejenisnya serta memenuhi rukunrukun dan syarat-syarat didalam jual belinya. Transaksi online dibolehkan menurut Islam berdasarkan prinsip-prinsip yang ada dalam perdagangan menurut Islam.

Pembahasan

Jual beli ialah suatu perjanjian tukar menukar benda atau barang yang mempunyai nilai, secara sukarela diantara pelaku jual beli.Pelaku dalam jual beli yaitu penjual dan pembeli.Penjual dan pembeli melakukan transaksi sesuai dengan perjanjian atau ketentuan yang telah dibenarkan syara' dan di sepakati.Transaksi jual beli yang di lakukan pada saat ini sudah didukung oleh kemajuan teknologi yang semakin pesat.Internet merupakan salah satu contoh kemajuan teknologi yang dapat digunakan sebagai media transaksi jual beli.Jual beli online atau Ecommerce merupakan transaksi jual beli yang dilakukan menggunakan internet.jual beli online atau E-commerce ini dianggap praktis, cepat, dan mudah.Selain itu juga dapat meminimalisir pengeluaran dan memaksimalkan dalam meraih keuntungan. 
Persoalan mengenai transaksi jual beli online yakni dikarenakan pra pihak tidak bertemu secara fisik sehingga kesepakatan antara kedua belah pihak dilakukan secara el ektronik.Umunya penawaran dan akad dalam transaksi el ektronik dilakukan secara tertulis, dimana suatu barang di pajangan dilaman internet dengan dilebeli harga tertentu. Kemudian bagi konsumen atau pembeli yang menghendaki maka transfer uang sesuai dengan harga yang tertera ditambah ongkos kirim. Suatu akad dilakukan dengan isyarat saja bisa absah, terlebih dengan menggunakan tulisan, gambar atau ilustrasi yang lebih jelas.Isyarat dalam akad pada dasarnya mempunyai kekuatan hokum sebagaimana penjelasan dengan lisan.

Sementara mengenai akadnya barang dan uang sebagai pengganti harga barang, maka dalam transaksi elektronik atau e-commerce tidak dilakukan secara langsung pada dunia nyata.Dalam hal bentuk dan wujud barang yang menjadi obyek transaksi, dalam e-commerce biasanya hanya berupa gambar (foto atau video) yang menunjukan barang aslinya kemudian dijelaskan spesifikasi sifat dan jenisnya.Pembeli dapat dengan bebas memilih barang sesuai dengan spesifikasi yang di inginkan. Barang akan dikirim setelah uang dibayar pada pihak Tokopedia.

Mengenai system pembayaran atau penyerahan uang pengganti barang, maka umunya adalah dilakukan dengan cara transfer. Bila system yang berlaku seperti ini, maka pada dasarnya jual beli ini adalah jual beli salam. Pembeli memilih barang dengan spesifikasi tertentu, kemudian membayarnya dengan Tokopedia sebagai perantaranya, setelah itu barang akan diserahkan atau dikirim kepada pembeli. Adapun system salam yang dilaksanakan dalam e commerce, maka rukun dan syaratnya juga harus sesuai dengan transaksi salam. Rukun salam yaitu :

a) Muslim (pembeli atau pemesan)

b) Muslam ilaih (penjual atau penerima pesanan)

c) Muslam fih (barang yang dipesan)

d) Ra'sul mal (harga pesanan atau modal yang dibayarkan)

e) Shighat ijab-qabul (ucapan serah terima)

Adapun mengenai syarat salam, secara umum sama dengan syarat akad jual beli, yaitu : barang yang dipesan merupakan sepenuhnya milik penjual, bukan barang najis dan bisa diserahterimakan. Hanya saja dalam akad salam tidak ada syarat bagi pemasan untuk melihat barang yang dipesan, ia hanya disyaratkan menentukan sifat-sifat dan jenis atau spesifikasi barang yang dipesan secara jelas.Seperti yang diungkapkan Hartina dalam wawancara sebagai berikut : "Aplikasi Tokopedia sangat membantu dalam transaksi jual beli, hanya saja penerapannya yang berbeda dengan transaksi jual beli di dunia nyata, jika di dunia nyata transaksinya secara langsung face to face sedangkan jual beli di Tokopedia di tangguhkan denga akad salam".

Berdasarkan berbagai penjelasan yang telah dipaparkan diatas maka cukup jelas bahwa, transaksi perdagangan atau jual beli yang dilakukan via media elektronik hukumnya sah.Kecanggihan media elektronik dapat membuat suasana dalam dunia maya menjadi seolah nyata. Namun demikian, transaksi tersebut dikategorikan sebagai transaksi kinayah yang keabsahannya dan kekuatan hukumnya sama dengan transaksi yang dilakukan secara langsung (sarih). 


\section{Kesimpulan}

Dalam pelaksanaan bisnisnya di Tokopedia menerapkan kejujuran, keramahan dan menjaga hubungan baik. Kejujuran dalam transaksi online di Tokopedia tercermin dalam penulisan deskripsi yang jujur apa adanya, menyajikan foto produk sesuai asli dan mengirimkan produk sesuai pesanan. Keramahan terlihat dari cara membalas pesan pembeli, menjaga sopan santun dan membalas sesegera mungkin. Meskipun transaksi di Tokopedia berupa online, menjaga hubungan baik dengan pelanggan berperan penting dalam merawat bisnis agar berkembang lebih pesat.Dalam transaksi jual beli di Tokopedia sudah menerapkan etika bisnsi Islam, meskipun mereka belum memahami betul etika bisnis Islam. Hal ini disebabkan karena tidak semua Tokopedia Community memiliki latar belakang ekonomi Syariah dan belum adanya sosialisasi atau sharing tentang etika bisnis IslamKendalanya karena tidak seluruh anggota Tokopedia Community beragama Islam.

Berbisnis melalui online satu sisi dapat memberi kemudahan dan menguntungkan bagi masyarakat. Namun kemudahan dan keuntungan itu jika tidak diiringi dengan etika budaya dan hukum yang tegas akan mudah terjebak dalam tipu muslihat, saling mencurangi dan saling menzalimi. Disinilah Islam bertujuan untuk melindungi umat manusia sampai kapanpun agar adanya aturan-aturan hukum jual beli dalam Islam yang sesuai dengan ketentuan syari'at agar tidak terjebak dengan keserakahan dan kezaliman yang meraja lela. Transaksi di Tokopedia Menggunakan Akad Bai' A ssalam Implementasi ini dilakukan karena secara umum transaksi jual beli yang dilakukan secara online akan menggunakan akad bai'assalam, yaitu dengan pembeli membayar terlebih dahulu kemudian penjual akan mengirim barang.

\section{D aftar Pustaka}

A fifi, J. (2019), D ikejar P ekerjaan,Pesanan dan Penghasilan, Yogyakarta : Laksana

Agung, G (2012), Rahasia Sukses Buka Lapak di Tokopedia, Jakarta : PT Elex Media Komputindo

Ahmad Nawawi (2019), Tinjauan Hukum Islam Terhadap Jual Beli O nline, Surakat : Universitas Muhammadiyah

Aryadi (2018), Jual Beli O nline Ibnu Tamiyah, Yogyakarta : Driandra Kreatif

Bekun , R.I (2004), Etika Bisnis Islam, Jakarta

Herdiansyah, H ( 2010), M etodelogi Penelitian Kualitatif untuk IImu-ilmu Sosial, Jakarta : Salembang Humanika

Indri dan Titik Wulan (2008), P rinsip-prinsip Ekonomi Islam, Jakarta : Lintas Pustaka Publisher

Purkon (2014), Bisnis O nline Syariah, Jakarta : PT Gramedia

Puspita, Y.P. (2019), A nalisis Keamanan Transaksi pada E-Commerce Sebagai M edia Bisnis, Bandung : Universitas Komputer Indonesia

Mardani (2014), H ukum Bisnis Syariah, Jakarta : Prenada Media Group

Mutiarasari ( 2019), Implementasi Bisnis O nline Syariah M elalui E-Commerce, Surabaya : Universitas Negri Sunan Ampel

Muhammad (2014), Etika Bisnis Islam, UPD AMP YKPN

Muhammad, M., Muhammad, M. R., Suhaimi, M. A., Hussin, H., Razi, M. J. M., \& Abdullah, K. (2013). Building trust in e-commerce from an Islamic perspective: A literature review. A merican A cademic \& Scholarly Research Journal, 5(5), 161.

Thimothy, J. (2010), M embangun Bisnis O nline, Jakarta : PT Elex Media Komputindo

Yulianti. R.T (2019), Praktek Etika Bisnis Islam pada Tokopedia Community Y ogyakarta, Yogyakarta : Universitas Islam Indonesia 


\section{Profil Penulis}

Siti Dwi Pujiyanti dan Anis Wahdi adalah mahasiswa dan dosen di Program Studi Perbankan Syariah, STAI Sayid Sabiq Indramayu Jawa Barat. Penulis dapat dihubungi di Email: pujidwi44@yahoo.com, aniswahdi.unipdu@gmail.com

\section{Accepted author version posted online: 20 June 2020}

$$
\text { (c) (1) }
$$

(C) 2020 The Author(s). This open access article is distributed under a Creative Commons

Attribution (CC-BY) 4.0 license 